\title{
Accessibility for All in Public Transport and the Overlooked (Social) Dimension-A Case Study of Stockholm
}

\author{
Vanessa Stjernborg ${ }^{1,2}$ (D) \\ 1 K2-The Swedish Knowledge Centre for Public Transport, SE-22236 Lund, Sweden \\ 2 Department of Urban Studies, Faculty of Culture and Society, Malmö University, SE-20506 Malmö, Sweden; \\ vanessa.stjernborg@mau.se
}

Received: 26 July 2019; Accepted: 2 September 2019; Published: 7 September 2019

check for updates

\begin{abstract}
Sweden was early to develop legislation related to accessible public transport for disabled people in 1979 and can therefore be seen as a forerunner. However, recent findings reveal widespread barriers in the Swedish public transport system and large variations between different parts of the country. This paper draws on empirical material consisting of complaints regarding accessibility left by travellers in Stockholm to a local transit company and aims to provide an overview of the character of complaints and to identify common themes through a qualitative content analysis. The results show that the most commonly reported challenge relates to boarding or getting off the vehicles, where the drivers are mostly described as the underlying reason for those difficulties. The narratives describe how some drivers misuse (or do not use) the accessibility equipment or show an abusive or attitudinal behaviour. The results support the body of literature on the meaning of continuous work with accessibility issues in public transport. Varying views on disability may have had a substantial impact on the development of our societies and on how the issues of accessibility in the public transport system have been prioritised or handled. Thus, this study highlights existing social barriers and variations in individual capacities as important factors that influence the experiences of public transport users. The study recommends an increased focus on educating drivers and staff about how to accommodate different groups of travellers. The study also recommends that transport providers consider drivers' working conditions (i.e., with the consideration of timetables and high time-pressure). Further research on how well accessibility adaptations in public transport actually work and how the users perceive them is necessary.
\end{abstract}

Keywords: disability; bus driver; inequality; social sustainability; functional limitations; barriers; uneven mobilities; social model; medical model

\section{Introduction}

The Global Goals and the 2030 Agenda for Sustainable Development highlight the importance of making cities inclusive, safe, and sustainable. They also emphasise the significance of providing accessible and sustainable transport systems for all citizens, especially by expanding public transport with a special focus on the needs of those in vulnerable situations, such as disabled people [1].

More than a billion people worldwide experience some kind of disability [2]. Disability is an umbrella term that covers impairments, activity limitations, and participation restrictions [3]. It generally relates to a poorer health, lower education achievements, and lower personal economy, and disabled people are usually in a higher risk of poverty [4,5]. According to the World Health Organisation, this is a result of "the lack of services available to them and the many obstacles they face in their everyday lives" [6]. Obstacles in everyday life involve a variety of hindrances, including transport related barriers. 
Further, being able to move around is essential in people's everyday lives-for managing everyday activities, for participating in society, and for maintaining social contacts [7]. The ability to use different modes of transport (such as walking, cycling, going by car, or going by public transport) is also essential for people to fully participate in activities outside their own home [8], and the World Health Organisation emphasises the importance of ongoing work for the removal of environmental and social barriers [3].

Public transport often plays a pivotal role in society - ensuring access to education, employment, daily activities, and social interaction and thereby enabling citizens to be a part of society [9]. Public transport is considered particularly important for disabled people [10,11], not least since this group can have more restricted access to other modes of transport, such as the access to a private car. Consequently, some researchers discuss "low-mobility populations", where the restricted access to modes of transport can mean marginalisation and low possibilities of influencing one's own life situation [11]. Other researchers highlight the "poor relation" the social dimension traditionally has had in transport research [12-14]. They point out how the lack of resources, in the form of access to modes of transport, can be referred to as transport poverty, which in turn can lead to social disadvantage and social exclusion. People with poor resources for mobility can also be at risk for what some researchers calls "a poverty trap": they might have to settle in more peripheral locations with fewer possibilities of local employment and with lower societal services offered [12]. Some researchers also criticise transit planners for mainly focusing on "the needs of a commuting population, often to the exclusion of low income, disabled or other marginalised riders" [15] (p. 925).

Furthermore, mobility is more than travelling from point A to point B (the physical movement alone). Instead, movement is located within a context of time and space [16]. Mobility depends on the context that the individual is embedded in, and interacting with, such as the larger society or the community, the household, and so on. Mobility is about individual capacities for movement-therefore, physical limitations in combination with environmental barriers can shrink individual possibilities for movement, which, in the end, can lead to isolation and exclusion [7]. Consequently, mobility is a resource that is unevenly distributed and differently accessed by different persons $[17,18]$ - the mobility of some can occur at the expense of the mobility of others [19]. Mobility is thereby a concept loaded with power and meaning and includes factors such as the type, strategies, and implications of movement. It also includes issues of inequality and uneven accessibility, something often referred to as "mobility justice" [18].

This paper draws on empirical material consisting of complaints regarding accessibility left by travellers to a local transit company in Stockholm, Sweden. The paper aims to provide an overview of the character of the complaints and to identify common themes from a qualitative approach. The paper begins with presenting different views on disability, followed by discussions about disability and barriers in public transport. Thereafter, it addresses questions about accessibility for all and public transport in Sweden. Subsequently, the paper presents the chosen study case-Stockholm, the capital of Sweden - then offers the study results along with the identified themes. The paper ends with an overall discussion about accessibility in public transport.

\subsection{Different Views on Disability}

There are several understandings of disability. The medical model of disability has received great attention. It views disability as a challenge related to the individual, one that is caused by illness and that requires treatment to follow normative values [20,21]. This model has been criticised for having an "objectified" view on disability and for focusing on treating the condition and the person with the condition rather than observing "the social processes and policies that constrict disabled people's lives" [21] (p. 5). Thus, this perspective regards restricted capacities as something related to the individual and not something related to the surrounding environment [20].

The social model arose from the reaction to the medical model in the early 1970s, advocated by the network of the Union of Physically Impaired against Segregation (UPIAS) [20,22]. They argue that 
it is "society which disables physically impaired people" (p. 197) and isolates and excludes disabled people from full participation [20]. Accordingly, this model distinguishes impairment from disability. Impairment is considered as individual and private, while disability is regarded as structural and public [20]. Further, within the social model, disability is a social construction created in the interaction between the individual and society, where society has the responsibility to strive for more inclusion.

The social model is considered politically effective in supporting the social movement of disabled people [20]; however, it has also faced criticism. Often, the critique points to theoretical shortcomings concerning the understanding of the individual and its impairments and to the limited explanation of the obstacles disabled people meet in the modern world. The model also fails to account for differences between disabled people [21-24]. Some critics argue that the UPIAS consisted of a small group of activists that were predominantly men with physical impairments, which could explain their "narrow understanding of disability" [20] (p. 197). According to Kafer [21] (p. 7):

The social model with its impairment/disability distinction erases the lived realities of impairment; in its well-intentioned focus on the disabling effects of society, it overlooks the often-disabling effects of our bodies.

This narrow understanding may have also resulted in some conditions being unexplored within disability studies, such as asthma, lupus, and diabetes [21]. Some claim that a shift in focus is necessary for "theorizing beyond the social model" [24] (p. 632).

The social model ideologically builds on materialism. Further, advocates of the social model believe that capitalism has meant an exclusion of disabled people from the labour market and from other essential parts of the society [22]. The current democratic Western societies are also characterised by market economy. However, some researchers argue that the market economy (and to some extent democracy) has a limited capacity to handle larger differences among citizens and only allows differences to a certain degree. The dilemma of a society that builds on freedom and equality is that it creates idealised individuals that citizens are expected to relate to [25]. Some researchers criticise the norms that define idealised citizen, and instead of questioning disability, they question the normative idealisation [21].

The social model also focuses on the built environment, such as buildings, pavements, transportation technologies, and so on. Since it is grounded in the view "that people are disabled not by their bodies but by their inaccessible environments" [21] (p. 129), some researchers believe this view has prevented disability studies from acquiring a more comprehensive perspective. According to Kafer [21] (p. 129),

Stairs can be replaced or supplemented with ramps and elevators, but what about a steep rock or a sandy beach? Like stairs, both pose problems for most wheelchair users.

Researchers emphasise the importance of observing "the complexity of the lived experience of disability" and recognising the strong interlinks of social and individual aspects [21]. The wider perspective, which recognises the context (social, cultural, geographical) the individual is situated in as well as individual capacities, should not be ignored.

\subsection{Disability and Barriers in Public Transport}

Despite the active efforts to remove physical barriers in public transport in several parts of the world, research still points to widespread challenges [26,27]. A recent study from the United States including over 4000 respondents shows that barriers in public transport are still both "physical and attitudinal in nature" [27] (p. 52). The most commonly reported barriers in the study were "an inadequate transit system", "drivers not calling out stops", and "inappropriate driver attitude". The researcher stresses the importance of continuing the work with removing physical barriers as well as the importance of offering educational opportunities to increase knowledge among employees about how to meet the needs of different groups [27].

An overview of research focusing on public transport and disability, including 344 publications, shows that research about accessibility for all in public transport generally has focused on physical 
barriers and informational barriers to a higher extent than on social barriers [28]. Physical barriers in public transport refer to poor design and maintenance of pedestrian facilities as well as stations and bus stops-such as narrow pavements, high kerbs, uneven or slippery surfaces, lack of benches, stairs without handrails, vehicles without ramps, ramps with low usability, and so on [29-32]. Informational barriers involve difficulties for some travellers to assimilate verbal, written, and visual information in the public transport system because of shortcomings in design or available information channels, among other things. They can also result from differential capacities of orientation in the public transport system. Research about informational barriers often deals with the development of new technology and the development of public information systems [33], digital aids through applications to smartphones [34], and educational programmes developed for disabled people to teach them how to travel with public transport [35]. Social barriers can be caused by other passengers [36] or by drivers and staff [37] - they can also result from feelings of insecurity when travelling by public transport [15].

\subsection{Social Barriers in Public Transport}

The lower focus on social barriers has been criticised by some researchers, indicating the importance of structural preconditions, good service, and positive attitudes from drivers and staff in public transport. Tillman et al. [37] (p. 313) concludes,

The discussion on accessibility is mainly focused on technical, structural, and constructional facts (e.g., kneeling buses). Even though the structural preconditions are essential, social barriers such as rejection by bus drivers or other passengers are relevant as well.

The Human Rights Commission has also raised this question. They highlight the importance of quality-from accessible vehicles to a good service from companies and drivers—and they describe how these attributes are linked together:

When it comes down to it, all the accessible vehicles in the world won't make a difference without good service and positive attitudes on the part of the bus companies and drivers [37] (p. 313).

Some studies have found that factors such as stressed drivers can be a barrier for travelling with public transport, which can create feelings of insecurity and unsafety. Travellers point to the behaviour of some drivers as a cause for stress and discomfort. Narratives in the studies describe how some drivers drive away before the passengers are seated or how some drivers do not use the accessibility equipment correctly, such as misusing the courtesy function of the bus or stopping far from the platform $[15,26,27,36]$. One study includes narratives of how some drivers have shown abusive or discriminatory behaviour against some disabled passengers [30].

Crowded spaces $[15,37,38]$ and other passengers are other factors that create barriers in public transport $[36,37]$. For instance, crowded spaces on board the vehicles can create feelings of unsafety and insecurity for some [15]. Velho et al. describe how wheelchair priority spaces are "a key source of anxiety" for some when travelling by public transport [10] (p. 29)-they also describe an ongoing struggle for space, which is particularly noticeable for people with wheelchairs-possibly due to not having enough space to move around with the wheelchair, having to share space with other passengers, or not being able to travel with a friend also with a wheelchair [10].

Barriers of any kind can mean the avoidance of travelling by public transport, which can increase the risk of marginalisation and exclusion of often already vulnerable groups [11,15]. Therefore, it is important to support the full participation of disabled people in the transport system and to understand the role of transportation in exclusion and marginalisation [11].

\subsection{Public Transport in Sweden and Accessibility for All}

The EU's Public Passenger Transport Regulation defines public passenger transport as "passenger transport services of general economic interest provided to the public on a non-discriminatory and continuous basis" [39] (p. 10). 
Public transport in Sweden is regulated by The Public Transportation Act (2010:1065) implemented in early 2012 [40]. Briefly, the law implies that every region should have a public transport authority responsible for public transport within the region as well as for cross-regional public transport. The new law also allowed "public transport companies to freely establish commercial public transport in all geographical market segments" [39] (p. 9). The former restriction against this matter was removed, and the change "was expected to increase the dynamics of public transport market and thus help to bring about a broader range of public transport and increased use of transportation" [39].

Sweden was a forerunner in developing legislation related to accessible public transport for disabled people (1979:558) [41]. Six years later, the initiative was followed by the Transport act in Great Britain, and eleven years later, the Americans with Disabilities Act in the United States [42]. Further, in the beginning of 2009, the UN's Convention on the Rights of Persons with Disabilities (CRPD) came into force in Sweden as well (Prop. 2008/09:28) [43], which forms the foundation for Sweden's policy of disability (Prop. 2016/17:188) [44]. The ambition with the convention is, among other things, to intensify efforts made to eliminate barriers for participation and inclusion in society-focusing on enabling disabled people to be active members of society, with the same rights as others [43].

However, a recently conducted overview made by Transport Analysis (a Swedish government agency) identified a number of shortcomings concerning accessibility issues in public transport in Sweden. For instance, it found that the responsibility and the regulations concerning accessibility in public transport are fragmented. The initiatives are mostly pervaded by single technical and physical measurements in infrastructure and in vehicles, often with a lack of a whole-travel-chain perspective. The coordination and the collaborative planning initiatives are sporicidal and vague, and an overall responsibility for following up on different accessibility efforts is missing. The overview concluded that the management of objectives is insufficient and that accessibility issues are handled, not as an integrated part of the overall quality system of public transport, but as single efforts for people with special needs [45].

According to a report from the Swedish Association of Local Authorities and Regions (SKL), there are great variations between Sweden's different regions regarding accessibility in public transport, not least concerning buses. On average, around $74 \%$ of the buses were regarded as accessible in 2015; however, there were major differences between the counties, the lowest accessibility being 19\% (Västerbottens County) and the highest being around 100\% (Stockholm County). The report concluded that the knowledge about how well those adaptations actually work, and how the users perceive them (usability), is rather limited [46].

Furthermore, travel surveys recently conducted in Sweden show that people with functional limitations travels less by car (both as a driver and as a passenger) than the overall population. However, they use the car as a mode of transport to a higher extent than public transport compared to the overall population. For every trip with public transport for disabled people, they take 5.7 car trips (compared to 3.7 car trips per trip with public transport for the overall population) [47]. Moreover, people with reduced locomotion report the lowest number of daily trips, with an average of 0.9 trips per day (compared to 1.6 trips for the overall population) [45]. In a recent population survey, stress, long waiting times, number of changes, difficulty in boarding the vehicles, and limited space were listed as common challenges within public transport [45].

\subsection{Study Case: Stockholm}

Stockholm is the capital of Sweden. In 2018, the municipality had approximately 962,000 inhabitants. The Greater Stockholm Local Transit Company (SL) is the main responsible actor of public transport in the region-responsible for the metro, the buses, and commuter trains and boats and responsible for public tender of public transport. The region of Stockholm's vision is that public transport should contribute to making Stockholm the most attractive conurbation in Europe. According to SL, the daily number of trips with public transport in the whole county is about 900,000 trips. Around six procured companies are running the traffic. 
SL have established guidelines concerning accessibility for children, older people, and people with functional limitations. The guidelines were set in 2008 and have since then been revised six times. The guidelines are based on current laws and directions and especially human right laws, such as the UN's Convention on the Rights of Persons with Disabilities and the Convention on the Rights of the Child. The guidelines cover everything from, for example, the personal treatment of disabled people and education of employees, to information in stations and on-board the vehicles (written and verbal) [48]. (According to the guidelines, all employees (interns as well as employed) must complete a basic education about accessibility; the Convention on the Rights of the Child; and personal treatment of children, older people, and travellers with functional limitations. Further education should occur at least every three years.)

According to SL, all buses in Stockholm are low-floor buses with the accessibility function to "courtesy the bus", which is a function controlled by the drivers that allows them to lower the entry side, creating a very small (or none) height difference between the vehicle and the curb (concerns bus stops that have an elevated curb). Most bus stops in the urban parts of the county have bus stops with an elevated curb. All buses are equipped with a ramp by the middle door of the vehicle. According to $\mathrm{SL}$, the driver is responsible for unfolding the ramp when necessary. The buses are also designed with a space for wheelchairs [49].

The metro has 100 stations, where all (except three) have the platform and the entry to the trains in the same height (a so-called low entry). If the traveller needs to use the ramp, according to SL, he or she will get assistance from their "ramp service" (the traveller, preferably in good time, can call a number and ask for this service).

The stations and the vehicles are also equipped with verbal information and different signals for guiding travellers. To make it easier for travellers to know which direction the trains are going, they have a female voice reciter for trains that are going north and a male voice reciter for trains going south. The digital destination signs are equipped with "pratorer", which are audio aids that automatically read information about the different departures when the travellers stand close to the signs. The stations and the platforms are equipped with tactile paving and contrast markings to facilitate orientation. SL also offers a free escort service; the escort helps travellers find their way or assist them when changing trains or buses, but the traveller must order the service no later than half an hour in advance. Most of the stations are equipped with an elevator (with a few exceptions). SL also offer an accessibility guarantee. The purpose of guarantee is to make sure that travellers with functional limitations can reach their destination even when something unexpected happens. For example, when elevators or ramps are broken, if there is a lack of information in the announcements, if there is a vehicle without a low entry (when it is supposed to be a vehicle with low entry), and so on. Those travellers can then be compensated with alternative transportation (for example, a taxi) or reimbursement [49].

\section{Materials and Methods}

The empirical material consists of collected complaints made by travellers concerning accessibility in public transport that SL has received between January and October 2018. The total number of complaints is 389 . Five complaints were excluded for containing only positive feedback or being duplicates. Generally, complaints can be left to SL through different channels, including through social media like Facebook, by phone, or by e-mail. The empirical material is collected in an Excel file containing information about departure/destination, date and time, route number, through which channel SL received the complaint, and a shorter description of the complaint. In some cases, where the traveller has left written complaints, the complaint description is the travellers' own words. In other cases, descriptions consist of secondary data summarised by SL's customer service employee who received the phone call. Most of the complaints were left via phone calls.

The complaints are divided into the following categories: courtesy of bus/closeness to the curb/ramp, elevator/escalator availability, escort service, timetables, and other (see Table 1). These 
categories were developed by SL. The analysis in this study focuses mainly on the detailed written text explaining the incident (the shorter description of the complaint).

Table 1. Complaints divided into categories $(\mathrm{N}=389)$.

\begin{tabular}{|c|c|c|c|}
\hline \multicolumn{2}{|c|}{ Category } & \multirow{2}{*}{$\begin{array}{l}\text { Number of } \\
\text { Complaints }\end{array}$} & \multirow{2}{*}{$\begin{array}{l}\text { Description } \\
\text { Mostly about how the driver is (not) using the accessibility } \\
\text { equipment of the buses. }\end{array}$} \\
\hline A & $\begin{array}{l}\text { Courtesy of the bus/closeness to } \\
\text { the curb/ramp }\end{array}$ & & \\
\hline A & Courtesy of the bus * & 186 & \\
\hline A & Closeness to the curb * & 37 & \\
\hline A & Closeness to the ramp * & 16 & \\
\hline B & Elevator/escalator availability & 136 & Mostly about elevators and escalators being out of function. \\
\hline$C$ & Escort service & 8 & $\begin{array}{l}\text { Mostly about escorts not showing up and } \\
\text { misunderstandings between the escort and the traveller. }\end{array}$ \\
\hline $\mathrm{D}$ & Timetables & 9 & $\begin{array}{l}\text { Mostly concern posting of timetables (with some comments } \\
\text { about how not all people use smartphones, etc.) }\end{array}$ \\
\hline E & Seating & 4 & $\begin{array}{l}\text { Mostly about too few seats or seats for disabled people } \\
\text { being occupied by other passengers. }\end{array}$ \\
\hline F & Other & 18 & $\begin{array}{l}\text { Broken lights that can trigger epileptic seizure, inadequate } \\
\text { announcements or signage, lack of personal continuity with } \\
\text { employees, and so on. }\end{array}$ \\
\hline
\end{tabular}

Note: ${ }^{*}$, one complaint can include several themes.

A qualitative content analysis was conducted in a stepwise manner. Content analysis commonly focuses on the manifest content (i.e., the content that is clearly pronounced in texts), and the core feature is the creation of categories. However, interpretations of latent content can also occur [50]. In this case, the focus was mainly on the manifest content.

Initially, the researcher read all the complaints to get a feeling for the material and to decide how well structured the categories developed by SL were and to which extent the categories were useable in this case. The researcher found the pre-developed categories useful. The category that contained the largest share of complaints was also the category with the most detailed descriptions, and the main focus of the analysis is on this category. The descriptions here mostly concerned trips taken with buses. The other categories are also briefly described in the results; however, most of the other complaints contained more detailed information about the use of the accessibility guarantee.

After reading the whole material, the researcher worked with one category at a time and read the complaints again. After reading the material again (category for category) to search for similarities, the researcher conducted a coding in themes in the excel-sheet, especially relevant for category A. In addition to the challenges described in this category related to the courtesy of the bus and so on, most of the narratives contained descriptions from a wider perspective about, for example, the behaviour of the driver. The researcher coded the material with consideration of both the incident (courtesy of the bus, closeness to the curb, or closeness to the ramp) and other circumstances, such as the behaviour of the driver, help from other passengers, feelings of exposure and vulnerability, and requests for improved education (see sections in the results). In a handful of cases, the descriptions concern complaints from people with strollers who had problems getting off/on the buses. Mostly, these descriptions include narratives about how both disabled people and people with strollers experienced challenges because of, for example, no lowering of the bus. In a few cases, the complaints only concerned people with strollers who had experienced challenges because of no use of the courtesy function. Since the challenge was similar to that for people with functional limitations, those few cases were kept included in the material.

\section{Results}

This section presents the results of the case study, and it is structured based on the identified categories and themes. The largest category is courtesy of the bus, its closeness to the curb when stopping the vehicle, and accessibility ramps. The category is divided into themes about the behaviour of 
the driver, the need for help from other passengers, feelings of exposure and vulnerability, and requests of improved education of drivers as well as technical development of the vehicles. Other categories are complaints about elevators/escalators, timetables, escort, seating, and other. Herein, all the quotes are the author's translation from the original Swedish.

\subsection{Category A: Courtesy, Closeness to the Curb When Stopping the Vehicle, and Accessibility Ramps}

The largest share of complaints concerns the use of the courtesy function of the bus, which lowers the bus to facilitate getting on or off the vehicle. The complaints describe how some drivers claim that they do not know how to use the technique, claim that the function is out of order, or refuse to use the function. In many of the complaints, the traveller states that she/he pushed the button placed in the bus for the driver to know when to courtesy, but it was of no use.

I am tired of having to yell at the driver to lower [the bus]. Even when I press the button for handicaps, nothing happens.

Many narratives reveal a repeated behaviour among some drivers, and many of the complaints illustrate a daily challenge when traveling by public transport. The complaints prove how important this accessibility function is for some travellers. According to one traveller, she/he has left complaints about the lack of use of the courtesy function in the vehicles for years. She/he also describes how some drivers often either claim that the function is out of order or reply with ignorance, which is a common view overall in the collected material.

Most often, the driver claims the bus function for this is broken, or they just completely ignore it.

Another narrative expresses a similar sentiment:

Why does one always have to have the same discussion with your bus drivers? Can you please make it known that the bus can lower for a reason! [ ... ]. Some bus drivers even get irritated when one points this out. Absolutely crazy!

Many of the complaints also describe how the bus stops far from the curb, resulting in a wider gap and making it even more difficult to get on or off the vehicle. The narratives report how bus drivers claim, for instance, that they cannot drive further to the curb since they have to protect the tyres of the vehicle. Other complaints are about drivers not stopping parallel to the stop sign, which can make it difficult for the visually impaired when entering the bus.

Several complaints also describe how travellers almost fell because of too wide gaps between the curb and the vehicle or because the vehicle was not lowered as it was supposed to. In some cases, they describe how this made them actually fall:

The driver did not courtesy the bus and failed to stop it close to the curb. The customer steps out of the bus and ends up [falling] in the gap between the bus and the curb. The customer splits open the forehead and knee and is forced to seek care to get stitches.

Another narrative describes it as follows:

When the customer's friend was about to step off, the doors closed on the friend so they flew out and fell to the ground and were just lying there. The driver had not lowered the bus even though the customer's friend had a crutch and had difficulty walking. The driver did not even care to check what had happened and just drove off.

The complaints also contain statements about how walkers, strollers, and so on have been broken because of too wide a gap between the curb and the vehicle or because of the bus not lowering. Some statements report a misuse of the courtesy function: according to the narratives, some drivers 
would lower the bus while passengers were disembarking, which in some cases resulted in that wheels of walkers, strollers and the like were crushed between the vehicle and the curb.

Other complaints concern the use of accessibility ramps in the vehicles. The complaints are about difficulties with unfolding the ramp, and many of them describe how drivers and other employees either avoid helping them with the ramp or do not help them at all even when they ask for help. One complaint is from a traveller with a wheelchair who experienced that the staff/driver very seldom help with unfolding the ramp. She/he also states how some drivers had driven away, just leaving her/him at the bus stop.

The majority of the time, bus driver has ignored the customer and closed the doors and left. Once, the driver went back [in the bus] but did not bother opening the ramp, so the customer was left on the street.

Some of the complaints also include experiences of a lack of accessibility equipment in the replacement vehicles provided in times of regular vehicle malfunction. For example, some of the narratives describe how people with wheelchairs are sometimes stranded when the regular vehicle breaks down because the replacement vehicle has no space for wheelchairs or no courtesy function or ramp. One traveller describes how a power failure caused a disturbance in the train traffic, which meant that travellers had to go by replacement buses-something shown to be difficult since the buses were not accessible.

Three buses within 45 minutes, all very fine tourist buses, with high entrance steps, and no room for wheelchairs. When the fourth bus was the same, and it was impossible to get a taxi, I gave up. Three people with strollers, one in a wheelchair, and two with walkers were left standing there.

\subsubsection{Nonchalant or Abusive Behaviour of Some Drivers}

Many of the complaints in the first category point to an underlying theme-nonchalant or, in some cases, abusive behaviour of some drivers. Travellers describe how they are ignored when asking for help with the ramp or with lowering the bus; they also mention how some drivers are rude to them, mocking them or using pejorative language regarding their disability and, in a few cases, threatening them. A number of narratives describe being exposed to uncomfortable situations, especially when asking some drivers for help with the ramp or when asking them to lower the vehicle.

One example from the collected material is a complaint left by a traveller with wheelchair. According to the narrative, the driver did not lower the bus nor open the middle doors, so the traveller had to enter the vehicle from the front door. The traveller explains how she/he was stuck in the narrow passage inside the bus trying to reach the designated space for wheelchairs. According to the statement, the whole sequence was being filmed and sent to the operator.

The driver just hit the gas, and the customer had to hold fast to the armrests, close to falling out. In the end, the customer could not take it anymore and asked the driver to stop the bus, which also happened. However, the driver was not helpful and the customer had to roll the wheelchair backwards out of the bus. There is a video of the incident that shows all the other passengers yelling at the driver to let the customer off [ ... ] When the customer finally got off, the driver gave the customer the finger.

Another narrative explains how the driver chose not to use the courtesy function of the vehicle and was rude to a traveller that questioned the behaviour.

The customer says the driver [ ... ] did not lower the bus on several occasions when older travellers were getting on (one of them had a wheelchair), and they had to get help from other passengers to get on and off. The customer asked the driver if the bus was malfunctioned, but he answered rudely, "Shall I lower the bus for every old lady?" 
There are also narratives that illustrate how some drivers have threatened travellers to leave the bus when they questioned why, for example, the drivers did not lower the vehicle. One narrative is from a traveller that met a young girl with a wheelchair sitting and crying in a central square because she was denied from getting on the bus.

She [sees] a young girl in a wheelchair crying. When the customer asks what had happened, the young girl tells her that a driver refused to let her get on the bus because he did not want to lower it.

Another narrative recounts how a traveller, according to her/him, was called "a fucking idiot" when asking the driver to lower the vehicle to facilitate entering the vehicle for people with physical limitations. According to many of the statements, the drivers' behaviour means that travellers with physical limitations need help from other passengers to be able to get on or off the vehicle, and it is often described to cause feelings of exposure and vulnerability.

\subsubsection{Help from Other Passengers}

Several of the narratives describe how some travellers are put in uncomfortable situations when there is a lack of accessible ramps or when the vehicles are not lowered at bus stops. One narrative recounts how one traveller's son had to carry her/him on-board the vehicle because of this, and some of the narratives point to a repeated behaviour among some drivers. Another example is from a customer who was travelling with a wheelchair and who needed help from other passengers because of the lack of help from the drivers.

When the customer wanted to get on the bus, the driver refused to lower it. Some fellow passengers then lowered the ramp instead and helped the customer up; it was then that the driver lowered the bus a little. When the customer arrived at the bus stop close to home, the same thing happened. The driver did not lower the bus, so a few passengers shouted at the driver to do so, and the driver eventually did. When the customer was about to get off, the driver opened the doors but did not lower the bus. After a few seconds, the driver shouts, "are you going to get off or?"

Other narratives provide further examples of other passengers having to hold some travellers in their arms to support and escort them on or off the vehicles due to accessibility equipment not being used.

\subsubsection{Feelings of Exposure and Vulnerability}

Several narratives include descriptions of how the behaviour of some drivers create feelings of exposure and vulnerability among the persons subjected to their behaviour. Some of the statements also describe how this provokes feelings of anger, frustration, sadness, and embarrassment, among others:

It makes me so angry and irritated that there would be a problem almost every trip.

Or:

... the driver's problem with lowering the bus caused the customer to be embarrassed in front of the other passengers.

Some narratives describe feelings of frustration, where some travellers question whether they are desired or not within the public transport system. One traveller describes an already vulnerable situation where she/he becomes even more vulnerable within the public transport system because of shortcomings in accessibility, and she/he describes how this creates barriers in daily life:

The gist is that we functionally disabled people face obstacles when we want to go out and use public transport with you. All the pains and obstacles we already face are in fact enough 
as it is. But maybe that is the point?! That you want to get rid of us functionally disabled [ ... ] ... that advertisement that SL trots out in newspapers, on buses, subways, etc. about how you are so adaptable and so accessible for the physically disabled. But this is not true. As you certainly already know.

She/he continues to describe how the discussions about an accessible transport system feel like a mockery and how the whole situation creates feelings of exclusion.

All those advertisements and promises [ ... ] feel like mockery towards us functionally disabled. That we are mostly just in the way and an inconvenience. [ ... ] That the buses do not courtesy (despite one having pressed the blue button) applies about $99.5 \%$ of the times I have gotten on them [ ... ] makes the final outcome that I refrain from using your transportation, and I feel excluded from SL's public transport.

Other narratives further question the right to travel with public transport no matter the functional capacities. One narrative explains how the misuse of the courtesy function of vehicles has, according to this traveller, increased recently. She/he relates this to an increased stress among drivers, which then causes feelings of insecurity for her/him when travelling by public transport.

\subsubsection{Requests for Improved Education of Drivers and Technical Development of Vehicles}

Some of the narratives question the educational level of bus drivers. Several travellers ask for increased education about how to meet the needs of different groups of people, not least the needs of people with functional limitations, particularly in relation to getting on and off the vehicle. One traveller relates the problem to life conditions and health. The traveller describes how she/he is suffering from reduced locomotion and constant pain.

It happens all too often that the bus stop is too far from the curb, for example, or the driver does not lower the bus even when one presses the blue button. [ ... ] I do not know how you educate your bus drivers, but I think that information about this particular subject should be included in the education so that the already compromised life and health conditions of passengers do not get worse for taking the bus.

The complaints also contain requests of arranged anonymous control trips by the operator, evaluating how the trip actually works for people with different capacities or people travelling with a mobility aid. There are also wishes for a function where the vehicle is lowered automatically when stopping at a bus stop, such a technology is described by one traveller as "a source of benefit", both on an individual level and for the society as a whole.

\subsection{Category B: The Elevator/Escalator}

Most of the complaints in this category concern elevators that are out of order and situations where the travellers have asked for the accessibility guarantee. Some of the complaints mention how some elevators can be out of order for one or two months. In a few cases, the complaints are from people travelling with a baby stroller-they complain about broken elevators and stairs lacking ramps, sometimes making it impossible for them to reach the platform.

\subsection{Categories C-F: Timetables, Escort Service, Seating, and Other Issues}

The complaints about timetables mostly come from persons who ask for enlarged timetables. One of the complaints also contains a request for an automatic subscription of printed timetables for older people and others who do not use smartphones and other technologies.

The complaints about the escort service involve escorts who do not show up or misunderstandings between the escort and the traveller. One complaint describes the escort as unfocused and absent.

Concerning the seats, there are complaints about too low seats, making it hard to arise for some. Some complaints pertain to the inadequate number and marking of prioritised seats. They also include 
narratives about how travellers with functional limitations had to stand up during trips since no one was offering them their seat. Therefore, one traveller asks the public transport operator to run a campaign to raise awareness among other travellers about functional limitations and the importance of leaving a seat for passengers with functional limitations.

The complaints under the category "Other" concern several issues including insufficient lighting that might hinder those who are old or visually impaired, twinkling lights that might be a risk for epileptics, and shortcomings in information announcements both on board vehicles and in stations. One traveller complained that she/he constantly have to interact with different employees when contacting the operator, which she/he finds very stressful and causes feelings of anxiety and vulnerability-she/he emphasises the importance of continuity in her/his contact with the operator. Other complaints concern, for example, inadequate signage or digital signage that can be difficult to see for a person with visual impairment because of light reflections.

\section{Discussion}

This paper aims to provide an overview of the character of complaints concerning accessibility left to a public transport provider in Stockholm, Sweden. A qualitative content analysis was conducted in order to gain a deeper knowledge about (a) what travellers experience as barriers in public transport and (b) why they experience them as barriers. By examining the complaints, it was possible to identify the most occurring barriers-barriers that, among other things, cause feelings of anxiety and frustration, as well as feelings of exclusion and dejection. A majority of the complaints focused on the role of the bus driver and the obstacles caused by the driver's behaviour-something highlighted in other studies as well [26].

Many of the complaints report how drivers (for different reasons) chose not to use accessibility functions such as lowering the bus at bus stops. Earlier research has pointed to the fact that accessible vehicles and environmental barriers are important but that a wider and more holistic perspective is necessary [37]. However, much of the focus has traditionally been on physical barriers, while the social dimension has often been overlooked. The larger focus on physical barriers may have been affected by the view on disability brought by the social model of disability. Much of the focus dealt with barriers in the built environment rather than the lived experiences of disability, with their many variations [21]. Due to the larger focus on the built environment, it is understandable that the social dimension in public transport seems to have been relatively overlooked.

Furthermore, some researchers argue that the market economy offers a limited space for variations within the population, which has thereby supported normative values, creating idealized individuals that the citizens are expected to relate to [25]. People that do not correspond with those idealized creations might be particularly vulnerable and at risk of social exclusion. Sweden is characterized by a market-based mixed economy. The new public transport law [40] allowed public transport operators to freely establish commercial public transport [51]. The Swedish regions contracts transport companies to run public traffic through a procuring process. In recent years, passenger incentives have also been increasingly common, aiming to increase the number of passengers by introducing passenger-incentive contracts. In the contracts, the operator "revenue comprises production-related revenue and a per-passenger-based incentive payment" [52] (p. 3). The Swedish public transport system today is also highly focused on increasing its market share compared with the car [53]. With such a development, it might be reasonable to believe that most of the emphasis by the transport operators lies on the "ideal traveller". The "ideal traveller" is according to Lubitow et al. a "white, male, able-bodied, financially stable" person that primarily uses public transport to get to and from work [15] (p. 934). However, this description is only applicable to a part of the population, and it can lead to the exclusion of other travellers. Mobility possibilities are not evenly distributed $[17,18]$, rather, they are influenced by context, power, and individual capacities. Some researchers have criticised how transport planners generally seem to have focused on the needs of an overall commuting population, often at the expense of other groups [15]. 
Several of the complaints mentioned stressed drivers as the cause for inconvenient situations and some complaints even stated how this has resulted in feelings of being un-prioritised by public transport. This could serve as an illustration of how the mobility of some often comes at the expense of others, which also contributes to inequalities and uneven opportunities. Much of the ambition in public transport today is about being more effective, for instance, through tighter timetables and digital payment possibilities and so on. Such adaptions might favour the needs of a commuting population, but they may also reduce the possibilities to travel for others. SL claims to offer high accessibility, and the public transport in Stockholm is also regarded as one of the most accessible in Sweden. However, accessibility from this perspective mostly concerns the built environment and the vehicles, such as elevated curbs or low-floor buses. Thus, the knowledge about how well those adaptations actually work and how the users perceive them is rather limited [46]. A common critique towards the social model of disability is that "it overlooks the often-disabling effects of our bodies" [21] (p. 7) and that it often fails to consider differences between people [21]. This can cause contradictions and eventually lead to the exclusion of those who do not fit into this view. One of the narratives was particularly strong in illustrating such a contradiction:

[T] That advertisement that SL trots out in newspapers, on buses, subways, etc. about how you are so adaptable and so accessible for the physically disabled. But this is not true.

The complaints about accessibility functions not being used properly are also illustrative examples of a situation where the accessibility problem is considered "solved" but the problem remains because of other factors. Again, accessibility is not only about physical barriers or the built environment but also about the whole context, which includes individual capacities and the physical and social surroundings.

Further, while this study provides an overview of the main complaints regarding accessibility in Stockholm's public transport, the qualitative approach it has undertaken also gives a deeper understanding of the underlying reasons behind these complaints. However, the study is rather limited, and it is not possible to draw any conclusions over how widespread those challenges actually are and whether there are other challenges not captured in the collected material. Therefore, it is essential to illuminate those issues further. Stockholm is also considered at the forefront when it comes to accessibility in public transport from a national perspective, and it would be interesting to compare national differences. Moreover, studies on barriers in public transport also often appear to focus on reporting diverse predefined hindrances in different surveys without any deeper analysis of why those are experienced as barriers [28]. Challenges related to getting on and off the vehicle are still generally reported as a common occurrence [45], despite being an issue under attention for many years. However, if the accessibility equipment is not used as intended, it is understandable that many people still consider getting on or off the bus a challenge-even though they are travelling with so-called "accessible" low-floor buses.

Finally, physical and social barriers are linked together, and they can create exclusion and isolation, to which already vulnerable groups are particularly exposed. For a more sustainable public transport system, it is therefore essential to establish an inclusive, barrier-free, and safe system that provides accessible public transport for all citizens.

\section{Conclusions}

The varying views on disability may have had a substantial impact on the development of our societies and on how the issues of accessibility in the public transport system have been prioritised or handled. The larger focus on the built environment may have caused the more intangible barriers, such as the behaviour of the drivers or the individual experiences of accessibility adaptations, to be somewhat sacrificed. Moreover, our societies and our economic system have a limited capacity to handle larger differences within the population, which affects the issues of accessibility in public transport as well. 
Today, public transport attracts large attention, not least in consideration of climate change and the increased focus on more resource-effective transport modes and a more sustainable transport system. The goals in Sweden for public transport are mainly about increasing market share-increasing the number of trips and decreasing car-based traffic in favour of public transport. These are important goals in the pursuit of a more resource-effective and sustainable transport system. However, the ambition of having public transport compete with the car puts a large pressure on the effectiveness of the public transport system and may also affect working conditions among drivers (i.e., high time pressure). Arguably, the prime focus of transport operators lies on the idealised traveller and, accordingly, people who do not fit into this standard become less of a priority. This could also partly explain why the responsibility and the regulations concerning accessibility in public transport were found to be fragmented and not treated as a standard quality factor for the whole organisation [45]. As concluded by Traffic Analysis, in order to create an accessible system for all, accessibility must not be seen as single technical and physical measurements in the infrastructure and vehicles but as an integrated part of the overall quality system of public transport [45].

Finally, public transport providers should ensure that their guidelines on staff education about different groups are being enforced - they should also ensure a reasonable level of quality of this education and verify that the employees use this knowledge in practice. Discriminatory and abusive behaviour of any kind should be treated with zero tolerance in the organisation. It is also important to recognise that large variations could exist within the group and that people could experience public transport differently. The study also recommends for transport providers to consider drivers' working conditions-for instance with a focus on timetables and high time-pressure. Increasing the knowledge about how well accessibility adaptations actually work and how the users perceive them is also essential.

For Sweden, where different companies are contracted to run public transport, it is also essential to consider the above-mentioned issues when procuring public transport, and to set clear and high requirements of the operator concerning accessibility issues and the educational level of employees. Replacement vehicles in the case of vehicle malfunction or the disruption of regular traffic represent another important issue, and it is significant to ensure that these vehicles are also accessible.

Funding: This research received no external funding.

Conflicts of Interest: The author declares no conflict of interest.

\section{References}

1. The Global Goals-For Sustainable Development. Available online: https://www.globalgoals.org/11sustainable-cities-and-communities (accessed on 19 June 2019).

2. World Health Organization. Available online: https://www.who.int/news-room/fact-sheets/detail/disabilityand-health (accessed on 19 June 2019).

3. World Health Organization. Available online: https://www.who.int/topics/disabilities/en/ (accessed on 19 June 2019).

4. World Health Organization. Available online: https://www.who.int/features/factfiles/disability/en/ (accessed on 19 June 2019).

5. Lönnqvist, A. Att erövra världen: En rapport om sambanden mellan fattigdom och Funktionshinder [To Concure the World: A Report about the Connections between Poverty and Functional Limitations]; MyRight-Empowering people with disabilities, partly SIDA-financed report; MyRight-Empowering People with Disabilities: Stockholm, Sweden, 2017.

6. World Health Organization. Available online: https://www.who.int/disabilities/world_report/2011/en/ (accessed on 19 June 2019).

7. Urry, J. Mobilities; Polity Press: Cambridge, UK, 2007.

8. Risser, R.; Lexell, E.M.; Bell, D.; Iwarsson, S.; Ståhl, A. Use of local public transport among people with cognitive impairments-A literature review. Transp. Res. Part F 2015, 29, 83-97. [CrossRef] 
9. Stjernborg, V.; Mattisson, O. The Role of Public Transport in Society-A Case Study of General Policy Documents in Sweden. Sustainability 2016, 8, 1120. [CrossRef]

10. Velho, R.; Holloway, C.; Symonds, A.; Balmer, B. The Effect of Transport Accessibility on the Social Inclusion of Wheelchair Users: A Mixed Method Analysis. Soc. Incl. 2016, 4, 25-35. [CrossRef]

11. Jansuwan, S.; Christensen, K.M.; Chen, A. Assessing the Transportation Needs of Low-Mobility Individuals: Case Study of a Small Urban Community in Utah. J. Urban Plan. Dev. 2013, 139, 104-114. [CrossRef]

12. Lucas, K.; Mattioli, G.; Verlinghieri, E.; Guzman, A. Transport poverty and its adverse social consequences. Proc. Inst. Civ. Eng. Transp. 2016, 169, 353-365. [CrossRef]

13. Lucas, K.; Jones, P. Guest Editorial: Social impacts and equity issues in transport-An introduction. J. Transp. Geogr. 2012, 21, 1-3. [CrossRef]

14. Cresswell, T. Towards a Politics of Mobility. Environ. Plan. D 2010, 28, 17-31. [CrossRef]

15. Lubitow, A.; Rainer, J.; Bassett, S. Exclusion and vulnerability on public transit: Experiences of transit dependent riders in Portland, Oregon. Mobilities 2017, 12, 924-937. [CrossRef]

16. Cresswell, T. On the Move: Mobility in the Modern Western World; Routledge: New York, NY, USA, 2006.

17. Sheller, M.; Urry, J. The New Mobilities Paradigm. Environ. Plan. A 2006, 38, 207-226. [CrossRef]

18. Sheller, M. Mobility Justice: The Politics of Movement in an Age of Extremes; Verso: London, UK, 2018.

19. Graham, S. Cities under Siege-The New Military Urbanism; Verso: London, UK, 2010.

20. Shakespeare, T. The Social Model of Disability. In The Disability Studies Reader, 5th ed.; Davis, L.J., Ed.; Routledge: New York, NY, USA, 2017; pp. 195-203.

21. Kafer, A. Feminist Queer Crip; Indiana University Press: Indiana, IN, USA, 2018.

22. Oliver, M. The social model of disability: Thirty years on. Disabil. Soc. 2013, 28, 1024-1026. [CrossRef]

23. McRuer, R. Crip Theory; Cultural Signs of Queerness and Disability; New York University Press: New York, NY, USA, 2006.

24. Goodley, D. Dis/entangling critical disability studies. Disabil. Soc. 2013, 28, 631-644. [CrossRef]

25. Berg, S.; Grönvik, L. Crip Theory—En Preliminär Positionering [Crip Theory-A Preliminary Positioning]. Available online: http://enhemlighet.se/wp-content/uploads/2012/09/CripTheory.pdf (accessed on 25 August 2019).

26. Park, J.; Chowdhury, S. Investigating the barriers in a typical journey by public transport users with disabilities. J. Transp. Health 2018, 10, 361-368. [CrossRef]

27. Bezyak, J.L.; Sabella, S.A.; Gattis, R.H. Public Transportation: An Investigation of Barriers for People with Disabilities. J. Disabil. Policy Stud. 2017, 28, 52-60. [CrossRef]

28. Stjernborg, V. Forskningsöversikt Om Funktionshinder I Kollektivtrafik [Research Overview of Functional Limitations in Public Transport]. Available online: https://www.trafa.se/globalassets/rapporter/ underlagsrapporter/2019/forskningsoversikt.pdf (accessed on 19 June 2019).

29. Risser, R.; Haindl, G.; Ståhl, A. Barriers to senior citizens' outdoor mobility in Europe. Eur. J. Ageing 2010, 7, 69-80. [CrossRef] [PubMed]

30. Wennberg, H.; Hydén, C.; Ståhl, A. Barrier-free outdoor environments: Older peoples' perceptions before and after implementation of legislative directives. Transp. Policy 2010, 17, 464-474. [CrossRef]

31. Carlsson, G. Travelling by Urban Public Transport: Exploration of Usability Problems in a Travel Chain Perspective. Occup. Ther. 2004, 11, 78-89. [CrossRef]

32. Ståhl, A.; Carlsson, G.; Hovbrandt, P.; Iwarsson, S. "Let's go for a walk!": Identification and prioritisation of accessibility and safety measures involving elderly people in a residential area. Eur. J. Ageing 2008, 5, 265-273. [CrossRef] [PubMed]

33. Waara, N.; Risser, R.; Ståhl, A. Exploring the influence of online traveller information services on the use of public transport by older people and people with functional limitations: A mixed methods approach. J. Technol. Disabil. 2013, 25, 15-25. [CrossRef]

34. Gallup, J.; Lamothe, S.N.; Gallup, A. Enhancing Transportation Education Using Mobile Devices and Applications. Teach. Except. Child. 2015, 48, 54-61. [CrossRef]

35. Haveman, M.; Tillmann, V.; Stöppler, R.; Kvas, S.; Monninger, D. Mobility and Public Transport Use Abilities of Children and Young Adults with Intellectual Disabilities: Results From the 3-Year Nordhorn Public Transportation Intervention Study. J. Policy Pract. Intellect. Disabil. 2013, 10, 289-299. [CrossRef]

36. Corr McEvoy, S.; Keenan, E. Attitudes towards People with Disabilities—what do people with intellectual disabilities have to say? Br. J. Learn. Disabil. 2013, 42, 221-227. [CrossRef] 
37. Tillmann, V.; Haveman, M.; Stöppler, R.; Kvas, S.; Monninger, D. Public Bus Drivers and Social Inclusion: Evaluation of Their Knowledge and Attitudes Toward People With Intellectual Disabilities. J. Policy Pract. Intellect. Disabil. 2013, 10, 307-313. [CrossRef]

38. Kaiser, H.J. Mobility in Old Age: Beyond the Transportation Perspective. J. Appl. Gerontol. 2009, 28, 411-418. [CrossRef]

39. Sveriges Riksdag (The Swedish Parliament). The Public Transportation Act-A Follow-up. Available online: https://www.riksdagen.se/globalassets/06.-utskotten--eu-namnden/trafikutskottet/tu-uppfoljning/ the-public-transportation-act--follow-up-summary.pdf (accessed on 20 June 2019).

40. Sveriges Riksdag (The Swedish Parliament). Lag (2010:1065) om Kollektivtrafik [Law of Public Transport]. Available online: https://www.riksdagen.se/sv/dokument-lagar/dokument/svensk-forfattningssamling/lag20101065-om-kollektivtrafik_sfs-2010-1065 (accessed on 20 June 2019).

41. Sveriges Riksdag (The Swedish Parliament). Lag (1979:558) om Handikappanpassad Kollektivtrafik [Law of Accessible Public Transport]. Available online: https://www.riksdagen.se/sv/dokument-lagar/dokument/ svensk-forfattningssamling/lag-1979558-om-handikappanpassad_sfs-1979-558 (accessed on 20 June 2019).

42. Nelson, J.D.; Wright, S.; Masson, B.; Ambrosino, G.; Naniopoulos, A. Recent developments in Flexible Transport Services. Res. Transp. Econ. 2010, 29, 243-248. [CrossRef]

43. Sveriges Riksdag (The Swedish Parliament). Regeringens Proposition 2008/09:28 Mänskliga Rättigheter för Personer Med Funktionsnedsättning [Governmental Proposition-Human Rights for People with Functional Limitations]. Available online: https://data.riksdagen.se/fil/0FBBB81F-DA1E-440C-915F-FDE03FF50247 (accessed on 20 June 2019).

44. Sveriges Riksdag (The Swedish Parliament). Nationellt mål och Inriktning för Funktionshinderspolitiken [National Goal and Direction for Policy of Disabilities] Prop. 2016/17:188. Available online: https: //www.regeringen.se/rattsliga-dokument/proposition/2017/05/prop.-201617188/ (accessed on 20 June 2019).

45. Trafikanalys. Kollektivtrafikens Barriärer-Kartläggning av Hinder i Kollektivtrafikens Tillgänglighet för Personer Med Funktionsnedsättning [Barriers in Public Transport-An Overview of Hinder in Accessibility for People with Functional Limitations]. Report 2019:3. Available online: https://www.trafa.se/globalassets/ rapporter/2019/rapport-2019_3-kollektivtrafikens-barriarer.pdf (accessed on 20 June 2019).

46. SKL. Öppna Jämförelser-Kollektivtrafik 2015 [Open Comparisions-Public Transport]; Sveriges Kommuner och Landsting LTAB: Stockholm, Sweden, 2015.

47. Trafikanalys. Resvanor Och Funktionsnedsättningar-Statistik ur Resvaneundersökningen [Travel Habits and Functional Limitation-Statistics from Survey of Travel Habits]. Report 2018:16. Available online: https://www.trafa.se/globalassets/rapporter/2018/rapport-2018_16-resvanoroch-funktionsnedsattningar-statistik-ur-resvaneundersokningen.pdf (accessed on 20 June 2019).

48. Trafikförvaltningen. Riktlinjer Tillgänglighet för barn, Äldre Och Personer Med Funktionsnedsättning [Guidelines for Accessibility for Children, Older People and People with Functional Limitations]; SL-S-419765; Trafikförvaltningen: Stockholm, Sweden, 2018.

49. SL. SL-Trafikens Tillgänglighet. Available online: https://sl.se/sv/info/resa/tillganglighet/tillganglighet/ (accessed on 20 June 2019).

50. Graneheim, U.H.; Lundman, B. Qualitative content analysis in nursing research: Concepts, procedures and measures to achieve trustworthiness. Nurse Educ. Today 2004, 24, 105-112. [CrossRef] [PubMed]

51. Transportstyrelsen. Kollektivtrafik [Public Transport]. Available online: https://www.transportstyrelsen.se/ sv/vagtrafik/Yrkestrafik/Kollektivtrafik/ (accessed on 24 August 2019).

52. Vigren, A.; Pyddoke, R. The Impact on Bus Ridership of Passenger Incentive Contracts in Swedish Public Transport. K2 Working Papers 2019:3. Available online: http://www.k2centrum.se/sites/default/files/fields/ field_uppladdad_rapport/wp_2019-3_incentives_web.pdf (accessed on 24 August 2019).

53. Stjernborg, V.; Nilsson, D. Kollektivtrafikens Bidrag Till Samhällsutveckling [The Contribution of Public Transport to Societal Development]. K2 Research 2018:2. Available online: http://www.k2centrum.se/sites/default/files/fields/field_uppladdad_rapport/kollektivtrafikens_bidrag_ till_samhallsutveckling_2018_2.pdf (accessed on 24 August 2019).

(C) 2019 by the author. Licensee MDPI, Basel, Switzerland. This article is an open access article distributed under the terms and conditions of the Creative Commons Attribution (CC BY) license (http://creativecommons.org/licenses/by/4.0/). 